\title{
Phaseolin from Phaseolus vulgaris bean modulates gut mucin flow and gene expression in rats
}

\author{
Carlos A. Montoya ${ }^{1} \dagger$, Pascal Leterme ${ }^{2}$, Véronique Romé $^{1}$, Stephen Beebe ${ }^{3}$, Jean Claustre ${ }^{4}$ \\ and Jean-Paul Lallès ${ }^{1 *}$ \\ ${ }^{1}$ INRA, UMR 1079 SENAH, F-35590 St-Gilles, France \\ ${ }^{2}$ Prairie Swine Centre, 2105 8th Street East, Saskatoon, SK, Canada, S7H 5N9 \\ ${ }^{3}$ Centro Internacional de Agricultura Tropical, AA 6713 Cali, Colombia \\ ${ }^{4}$ INSERM UMR 865, CNRS, Faculté R. Laennec, IFR62 Lyon Est, Université Claude Bernard Lyon 1, Lyon, France
}

(Received 5 January 2010 - Revised 19 April 2010 - Accepted 14 June 2010 - First published online 2 August 2010)

\begin{abstract}
Dietary protein might modulate mucin flow and intestinal mucin gene expression. Since unheated phaseolin from Phaseolus vulgaris bean is resistant to digestion and increases gut endogenous protein losses, we hypothesised that unheated phaseolin influences mucin flow and gene expression, and that phaseolin heat treatment reverses these effects. The hypothesis was tested using a control diet containing casein as the sole protein source and three other diets with casein being replaced by 33 and $67 \%$ of unheated and $67 \%$ of heated phaseolin. The rats were fed for $6 \mathrm{~d}$ and euthanised. Digesta and faeces were collected for determining digestibility and mucin flow. Gut tissues were collected for mucin (Muc1, Muc2, Muc3 and Muc4) and Trefoil factor 3 (Tff3) gene expressions. Colonic mucin flow decreased linearly with increasing the dietary level of unheated phaseolin $(P<0.05)$. Unheated phaseolin increased $\mathrm{N}$ flow in ileum, colon and faeces $(P<0.05)$, and reduced apparent $\mathrm{N}$ digestibility linearly $(P<0 \cdot 01)$. Heat treatment reversed all these changes $(P<0.05$ to $<0 \cdot 001)$, except mucin flow. The expressions of $M u c$ mRNA in gut tissues were influenced by dietary phaseolin level (ileum and colon: Muc3 and Muc4) and thermal treatment (ileum: Muc2; colon: Muc2, Muc3, Muc4 and Tff3) $(P<0.05$ to 0.001$)$. In conclusion, phaseolin modulates mucin flow and Muc gene expression along the intestines differentially.
\end{abstract}

Digestion: Mucin: Phaseolin: Rats

The storage globulin phaseolin represents about half of the total protein content of the common bean (Phaseolus vulgaris $)^{(1)}$. The nutritive value of phaseolin is limited by its low content in sulphur amino acids and tryptophan and its high resistance to enzymatic hydrolysis ${ }^{(2,3)}$. However, phaseolin digestion is markedly improved with heat treatment due to alterations in phaseolin structure ${ }^{(4,5)}$.

Unheated phaseolin and/or its digestion fragments exert a secretagogue activity on the gut of rats fed a single test meal since intestinal endogenous protein losses (e.g. shed cells, digestive enzymes, gastrointestinal mucus and blood serum proteins) increase when phaseolin intake increases ${ }^{(6)}$. These authors postulated that mucin could be a possible significant contributor to these losses ${ }^{(6)}$. By contrast, in a chronic feeding trial, the dietary level of unheated phaseolin had little effects on rat small intestine architecture and enzymatic activity $^{(7)}$.

The composition, thickness and protective effect of the mucus layer are determined by the dynamic balance between two processes: synthesis and secretion by goblet cells $v$. degradation by physical abrasion and proteolysis ${ }^{(8)}$. An intact mucus layer is required at the gut epithelial surface for optimal protection $^{(9)}$. Mucin could represent $11 \%$ of total endogenous $\mathrm{N}$ losses at the ileum of pigs ${ }^{(10)}$. Previous studies in singlestomached animals showed that food components, including fibre and protein source and their level of incorporation into the diet could stimulate mucin secretion in the small intestine $^{(11,12)}$. However, no information is available on the effect of prolonged intake of diets differing in phaseolin level or with heated phaseolin on mucin flow in the gut lumen and on mucin gene expression in gut tissues of rats.

The aim of the present study was to test the hypothesis that unheated phaseolin modulates mucin flow and tissue gene expression in the intestines of rats and that heat treatment of phaseolin abolishes these effects.

\section{Experimental methods \\ Phaseolin purification}

The bean cultivar used in the present study contained phaseolin of the $\mathrm{T}$ type. It was provided by the International Centre

Abbreviations: P0, casein control diet (no phaseolin); P33, diet containing phaseolin at $330 \mathrm{~g} / \mathrm{kg}$ total protein; P67, diet containing phaseolin at $670 \mathrm{~g} / \mathrm{kg}$ total protein; P67-H, diet containing heat-treated phaseolin at $670 \mathrm{~g} / \mathrm{kg}$ total protein; Tff3, trefoil factor 3.

* Corresponding author: Dr J.-P. Lallès, fax +332234850 80, email jean-paul.lalles@ rennes.inra.fr

$\dagger$ Present address: Riddet Institute, Private Bag 11 222, Palmerston North 4442, New Zealand. 
of Tropical Agriculture (Cali, Colombia). Phaseolin was isolated by successive protein solubilisation and precipitation steps as previously reported ${ }^{(7,13)}$. The final phaseolin precipitate was dialysed against distilled water, frozen and freeze-dried before being incorporated into the experimental diets. Phaseolin isolated with this protocol was found to be pure as revealed by SDS-PAGE ${ }^{(7)}$.

\section{Animals and diets}

The experiment was conducted in agreement with the guidelines of the National University of Colombia for care and use of laboratory animals ${ }^{(14)}$. Twenty young adult Wistar male rats with an initial body weight of 110 (SD 5) g were randomly allocated to one of the four treatments described below, and placed in individual metabolism cages (Tecniplast 150-300, Buguggiate, Italy) for the whole experimental period. The control diet (P0) contained casein as the sole protein source. In the other three diets, protein was provided at $33 \%$ (P33) and 67\% (unheated form; P67) and $67 \%$ (heated form; P67-H) by purified phaseolin, respectively. No attempt was made to incorporate $100 \%$ of protein as phaseolin because it was previously shown to drastically reduce food intake in our previous studies with rats $^{(7)}$. The complement of protein in the diets was casein (Table 1). Heat treatment of purified phaseolin was carried out under pressure at $121^{\circ} \mathrm{C}$ for $15 \mathrm{~min}$, as described previously ${ }^{(7)}$. Chromium oxide was added to the diets as an indigestible marker for determining the flow and the apparent digestibility of food

Table 1. Ingredient and analytical composition of the experimental diets

\begin{tabular}{lrrrr}
\hline & \multicolumn{4}{c}{ Experimental diet* } \\
\cline { 2 - 5 } & P0 & P33 & P67 & P67-H† \\
\hline Ingredients (g/kg DM) & & & & \\
Casein & 120 & 83 & 41 & 41 \\
Phaseolin $\ddagger$ & 0 & 35 & 70 & 70 \\
Starch & 599 & 601 & 608 & 608 \\
Sucrose & 100 & 100 & 100 & 100 \\
Ground rice hulls & 80 & 80 & 80 & 80 \\
Vegetable oil & 60 & 60 & 60 & 60 \\
Vitamin trace elements§ & 10 & 10 & 10 & 10 \\
Calcium phosphate & 14 & 14 & 14 & 14 \\
Calcium carbonate & 3 & 3 & 3 & 3 \\
Sodium chloride & 2 & 2 & 2 & 2 \\
Potassium chloride & 7 & 7 & 7 & 7 \\
Magnesium sulphate & 2 & 2 & 2 & 2 \\
Chromium oxide & 3 & 3 & 3 & 3 \\
Analysis (g/kg DM) & & & & \\
DM (g/kg) & 908 & 903 & 908 & 915 \\
Protein (N $\times 6 \cdot 25)$ & 96 & 103 & 96 & 96 \\
Ether extract & 65 & 65 & 64 & 66 \\
Ash & 71 & 67 & 67 & 64 \\
Neutral-detergent fibre & 63 & 70 & 70 & 67 \\
Gross energy (MJ/kg DM) & $16 \cdot 3$ & $16 \cdot 3$ & $16 \cdot 4$ & $16 \cdot 3$ \\
\end{tabular}

* Diets: P0, casein control; P33 and P67, diets with phaseolin T contributing to 330 and $670 \mathrm{~g} / \mathrm{kg}$ of total dietary protein. Casein was supplemented with $30 \mathrm{~g}$ DL-methionine/kg DM casein.

$\dagger \mathrm{P} 67-\mathrm{H}$, heat-treated $\left(121^{\circ} \mathrm{C}\right.$ for $\left.15 \mathrm{~min}\right)$ phaseolin

$\ddagger$ Purified phaseolin of the $\mathrm{T}$ type.

$\S$ Mineral and vitamin mixture supplied per $\mathrm{kg}$ of diet: $7.5 \mathrm{mg}$ vitamin $\mathrm{A} ; 0.2 \mathrm{mg}$ vitamin $\mathrm{D}_{3} ; 15 \mathrm{mg}$ vitamin $\mathrm{E} ; 6 \mathrm{mg}$ vitamin $\mathrm{K} ; 10 \mathrm{mg}$ vitamin $\mathrm{B}_{2} ; 35 \mathrm{mg}$ calcium pantothenate; $75 \mathrm{mg}$ niacin; $2.5 \mathrm{mg}$ vitamin $\mathrm{B}_{6} ; 0.05 \mathrm{mg}$ vitamin $\mathrm{B}_{12} ; 0.05 \mathrm{mg}$ biotin; $200 \mathrm{mg}$ choline; $150 \mathrm{mg} \mathrm{Mn;} 500 \mathrm{mg} \mathrm{Zn;} 40 \mathrm{mg} \mathrm{Cu}, 200 \mathrm{mg} \mathrm{Fe;} 2 \mathrm{mg}$ iodine; $0.5 \mathrm{mg} \mathrm{Se}, 1 \mathrm{mg}$ Co. components along the gut. The rats were fed the experimental diets for $6 \mathrm{~d}$ only because the amounts of purified phaseolin were limited. Food intake was fixed at $10 \%$ of body weight in order to limit food refusals ${ }^{(7,15)}$. The rats had free access to water.

\section{Collection and preparation of faeces, digesta and gut tissue samples}

Faeces were collected during the last day of the feeding experiment and mixed $(350 \mathrm{~g} / \mathrm{l})$ with cold saline $(9 \mathrm{~g} \mathrm{NaCl} / \mathrm{l})\left(4^{\circ} \mathrm{C}\right)$. At the end of the trial, rats had access to the experimental diets for $4 \mathrm{~h}$ and then were euthanised with an injection of Ketamine and Rompun ${ }^{\circledR}(1: 1, \mathrm{v} / \mathrm{v})$. Gut digesta and tissues were sampled as described previously ${ }^{(7,15)}$. All digesta present in the distal $20 \mathrm{~cm}$ of the small intestine (referred to as ileum) and in the whole colon were collected. Ileal and colonic digesta were gently flushed from the segments with $10 \mathrm{ml}$ of cold saline $(9 \mathrm{~g} \mathrm{NaCl} / \mathrm{l})\left(4^{\circ} \mathrm{C}\right)$ using a syringe. Gut digesta and faeces were immediately mixed with $40 \mathrm{~g} \mathrm{NaN}_{3} / 1$ with a final concentration of $2 \mathrm{~g} / \mathrm{l}$ in order to minimise protein degradation by bacterial enzymes. Digesta and faeces were fractionated into two aliquots that were frozen and stored at $-20^{\circ} \mathrm{C}$. An aliquot was kept frozen until mucin analysis, while the other aliquot was freeze-dried and ground ( $1 \mathrm{~mm}$ mesh screen) for digestion studies.

Whole tissue samples $(1.5 \mathrm{~cm}$ in length) were collected in the middle of the ileum and colon, opened longitudinally and washed three times in cold saline $(9 \mathrm{~g} \mathrm{NaCl} / \mathrm{l})\left(4^{\circ} \mathrm{C}\right)$. They were stored immediately in cold TRIzol reagent $\left(4^{\circ} \mathrm{C}\right)$, then frozen in liquid $\mathrm{N}_{2}$ and finally stored in a deep freezer at $-80^{\circ} \mathrm{C}$.

\section{Enzyme-linked lectin assay for high molecular weight mucin along the gut}

Ileal and colonic digesta and faeces were assayed for high molecular weight glycosylated mucin by enzyme-linked lectin assay using wheat germ agglutinin as the lectin, as described by Trompette et al. ${ }^{(16)}$. Casein, phaseolin and the experimental diets were also checked by enzyme-linked lectin assay test for possible lectin binding. Porcine gastric mucin (reference M1778; Sigma-Aldrich, Saiat-Quentin Fallavier, France) was used as the standard. Briefly, dilutions of standards and samples were prepared in carbonate buffer $\left(0.5 \mathrm{M}-\mathrm{Na}_{2} \mathrm{CO}_{3}, \mathrm{pH} 9.6\right)$ before being coated on ninety-six-well microtitre plates (reference 469914; NUNC microplates, Roskilde, Denmark; $100 \mu \mathrm{l} /$ well). After overnight incubation at $4^{\circ} \mathrm{C}$, the plates were washed four times with PBS Tween (1 g/l) (pH 7.2). Microplate saturation was made with $250 \mu \mathrm{l} /$ well of a PBS Tween solution of bovine serum albumin (20 g/l PBS Tween) incubated for $1 \mathrm{~h}$ at $37^{\circ} \mathrm{C}$. Plates were washed again, and $100 \mu \mathrm{l}$ of biotinylated wheat germ agglutinin (reference B-1025; Abcys, Paris, France; $5 \mathrm{mg} / \mathrm{l}$ ) in PBS Tween-bovine serum albumin was added and incubated for $1 \mathrm{~h}$ at $37^{\circ} \mathrm{C}$. Plates were washed, and $100 \mu \mathrm{l} /$ well of avidin-peroxidase conjugate (reference A-7419; Sigma) was added for $1 \mathrm{~h}$ at room temperature. After washing, $100 \mu 1 /$ well of $o$-phenylenediamine (OPD) solution (reference P-9187; Fast OPD, Sigma) was incubated in the dark at room temperature for 5-10 min. The reaction was stopped by adding $25 \mu \mathrm{l} /$ well of $3 \mathrm{M}-\mathrm{H}_{2} \mathrm{SO}_{4}$. Absorbance was read at 
$492 \mathrm{~nm}$ using an ELISA reader (Multiskan Spectrum reference 5118550; Thermo Electron Corporation, Vantaa, Finland). Mucin concentration in samples was calculated from porcine gastric mucin standard curve. Data were expressed as mg or $\mu \mathrm{g}$ mucin per $\mathrm{g}$ digesta or faeces, depending on its concentration along the gut.

\section{RNA extraction from gut tissues}

Gut tissue samples were homogenised in TRIzol reagent $(1 \mathrm{ml} / 100 \mathrm{mg}$ ) with tissue lyser (Qiagen Inc., Valencia, CA, USA) at room temperature. Then, $200 \mu$ l of chloroform was added, and the sample was mixed and centrifuged at $11300 \mathrm{~g}$ for $15 \mathrm{~min}$ at $4^{\circ} \mathrm{C}$. The chloroform upper phase was recovered, mixed with $500 \mu \mathrm{l}$ of isopropanol and centrifuged at $11300 \mathrm{~g}$ for $15 \mathrm{~min}$ at $4^{\circ} \mathrm{C}$. The precipitated RNA was rinsed with $75 \%$ ethanol, centrifuged at $7500 \mathrm{~g}$ for $5 \mathrm{~min}$ at $4^{\circ} \mathrm{C}$, and dissolved into $100 \mu \mathrm{l}$ of RNase-free water and stored at $-80^{\circ} \mathrm{C}$ until further analysis. RNA concentration and purity were determined by measuring the absorbance at 260 and $280 \mathrm{~nm}$ using an Agilent 2100 bioanalyser (Agilent Technologies, Palo Alto, CA, USA). Finally, samples were treated with DNase (DNA-free kit, Applied Biosystems, Foster City, CA, USA) following the manufacturer's recommendations.

\section{Quantitative real-time $R T$-PCR}

Quantitative real-time RT-PCR was conducted as previously reported $^{(16)}$ with slight modifications. Briefly, mucin complementary DNA rat $M u c 1, M u c 2, M u c 3, M u c 4$, trefoil factor 3 (Tff3) and $18 S$ mRNA were amplified by PCR using the primer sequences shown in Table 2. For retrotranscription, total RNA $(2 \mu \mathrm{g})$ was added with RNase-free water to a final volume of $20 \mu$ l. The reaction mixture (High Capacity complementary DNA Reverse Transcription Kit; Applied Biosystems) had a final volume of $20 \mu \mathrm{l}$, and contained $4 \mu \mathrm{l}$ of $10 \times$ RT buffer, $1.6 \mu \mathrm{l}$ of $25 \times$ deoxy nucleotide triphosphate, $4 \mu \mathrm{l}$ of $10 \times$ random primers, $2 \mu \mathrm{l}$ of RT $(50 \mathrm{Iu} / \mu \mathrm{l})$ and $8.4 \mu \mathrm{l}$ of sterile water. The reaction mixture and the sample were mixed together $(40 \mu \mathrm{l}$, final volume), then incubated at $25^{\circ} \mathrm{C}$ for $10 \mathrm{~min}$, at $37^{\circ} \mathrm{C}$ for $2 \mathrm{~h}$, and finally cooled on ice. Afterwards complementary DNA was ready for use in real-time PCR.

Table 2. Nucleotide sequences of the PCR primers used to measure the effect of phaseolin in rats

\begin{tabular}{|c|c|c|c|}
\hline Gene & Primer & Sequences $\left(5^{\prime}-3^{\prime}\right)$ & Reference \\
\hline $18 S$ & Sense & ACGGAAGGGCACCACCAGGAG & \\
\hline & Antisense & GCACCACCACCCACGGAAACG & 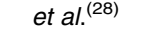 \\
\hline Muc1 & Sense & TCGACAGGCAATGGCAGTAG & Trompette \\
\hline Muc2 & $\begin{array}{l}\text { Sense } \\
\text { Antisense }\end{array}$ & $\begin{array}{l}\text { GCCTCAAACCCGTGCGTGTC } \\
\text { TCATTCACCAACCACTCATC }\end{array}$ & Lin et $a l^{(47)}$ \\
\hline Muc3 & $\begin{array}{l}\text { Sense } \\
\text { Antisense }\end{array}$ & $\begin{array}{l}\text { CTTGAGGAGGTGTGCAAGAAA } \\
\text { CCCCAGGGTGACATACTTTG }\end{array}$ & Han et al. ${ }^{(32)}$ \\
\hline Muc4 & $\begin{array}{l}\text { Sense } \\
\text { Antisense }\end{array}$ & $\begin{array}{l}\text { GCTTGGACATTTGGTGATCC } \\
\text { GCCCGTTGAAGGTGTATTTG }\end{array}$ & Han et al. ${ }^{(32)}$ \\
\hline Tff3 & $\begin{array}{l}\text { Sense } \\
\text { Antisense }\end{array}$ & $\begin{array}{l}\text { CCTGGTTGCTGGGTCCTCTG } \\
\text { GCCACGGTTGTTACACTGCTC }\end{array}$ & $\begin{array}{l}\text { Hoebler } \\
\quad \text { et al. }{ }^{(28)}\end{array}$ \\
\hline
\end{tabular}

Real-time PCR was performed in duplicate for each sample using ABI PRISM Sequence Detection System 7000 (Applied Biosystems). A reaction mixture containing the following components was prepared: $5.8 \mu \mathrm{l}$ ultrapure water, $0.75 \mu \mathrm{l}$ of forward and $0.75 \mu \mathrm{l}$ of reverse primer $(5 \mu \mathrm{mol} / \mathrm{l}), 12.5 \mu \mathrm{l}$ SYBR Green PCR Master Mix kit and $0 \cdot 2 \mu$ uracil-DNA glycosylase $(1 \mathrm{Iu} / \mu \mathrm{l})$ (Applied Biosystems). The reaction mixture $(20 \mu \mathrm{l})$ was mixed with sample complementary DNA $(5 \mu 1)$. The cycling conditions were as follows: $50^{\circ} \mathrm{C}$ for $2 \mathrm{~min}$ for uracil-DNA glycosylase action. Then, initial denaturation was conducted at $95^{\circ} \mathrm{C}$ for $10 \mathrm{~min}$ and then followed by forty amplification cycles of $95^{\circ} \mathrm{C}$ for $15 \mathrm{~s}$ and $60^{\circ} \mathrm{C}$ for $1 \mathrm{~min}$. The $M u c$ genes and Tff3 were expressed relatively to I8S RNA as reported previously ${ }^{(17)}$.

\section{Chemical analysis}

Diets were analysed for ash (AOAC 942.05), diethyl ether extract (AOAC 920.39) and neutral-detergent fibre (AOAC 2002.04). Gross energy was determined in diets using a Parr 1342 calorimeter (Parr Instruments, Moline, IL, USA). Diets, faeces and digesta were also analysed for DM (AOAC 930.15) and $\mathrm{N}$ (Kjeldahl method). Chromium concentration in diets, ileal and colonic digesta and faeces was determined colorimetrically after nitro-perchloric acid hydrolysis ${ }^{(18)}$.

\section{Digesta flow and digestibility calculations}

The flows of DM, $\mathrm{N}$ and enzyme-linked lectin assay mucin at the ileum, in the colon and in the faeces were calculated from marker concentrations in diets and digesta or faeces as reported previously ${ }^{(11)}$. Apparent ileal and faecal digestibilities of DM and $\mathrm{N}$ were calculated using the following equations $^{(19)}$ :

$$
\begin{aligned}
& \text { Apparent ileal digestibility of DM or } \mathrm{N} \\
& \qquad=\left(100-\left(\left(\mathrm{DM}_{\mathrm{i}} \text { or } \mathrm{N}_{\mathrm{i}} / \mathrm{DM}_{\mathrm{d}} \text { or } \mathrm{N}_{\mathrm{d}}\right) \times\left(\mathrm{Cr}_{\mathrm{d}} / \mathrm{Cr}_{\mathrm{i}}\right)\right)\right) \times 100
\end{aligned}
$$

Apparent faecal digestibility of DM or N

$$
=\left(100-\left(\left(\mathrm{DM}_{\mathrm{f}} \text { or } \mathrm{N}_{\mathrm{f}} / \mathrm{DM}_{\mathrm{d}} \text { or } \mathrm{N}_{\mathrm{d}}\right) \times\left(\mathrm{Cr}_{\mathrm{d}} / \mathrm{Cr}_{\mathrm{f}}\right)\right)\right) \times 100
$$

where $\mathrm{DM}_{\mathrm{i}}, \mathrm{N}_{\mathrm{i}}$ and $\mathrm{Cr}_{\mathrm{i}}$ are the DM, $\mathrm{N}$ and chromium contents of ileal digesta, and $\mathrm{DM}_{\mathrm{f}}, \mathrm{N}_{\mathrm{f}}$ and $\mathrm{Cr}_{\mathrm{f}}$ are those in the faeces; $\mathrm{DM}_{\mathrm{d}}, \mathrm{N}_{\mathrm{d}}$ and $\mathrm{Cr}_{\mathrm{d}}$ are the DM, $\mathrm{N}$ and chromium contents of the diet.

\section{Statistical analysis}

Two separate ANOVA of data were conducted using the Mixed Model procedure of Statistical Analysis System software package version 8.0 (SAS Institute Inc., Cary, NC, USA). In the first analysis, the effect of unheated phaseolin level $(0,33$ and $67 \%$ of total $N)$ in the diet was tested for linear and quadratic variations using polynomial orthogonal contrasts $^{(20)}$. The second ANOVA was conducted in order to test the effect of heat treatment of phaseolin, and diets with untreated phaseolin, heated phaseolin and casein were compared. When the $P$ value of treatment effects was $\leq 0 \cdot 10$, the diets were compared two by two using appropriate contrasts ( $\mathrm{P} 0$ v. $\mathrm{P} 67, \mathrm{P} 0$ v. $\mathrm{P} 67-\mathrm{H}$ and $\mathrm{P} 67$ v. $\mathrm{P} 67-\mathrm{H})$. 


\section{Results}

The voluntary DM and $\mathrm{N}$ intakes were on average across treatments 9.6 (SEM 0.14) g/d and 151 (SEM 4) mg/d, respectively, and did not differ significantly between treatments $(P>0.05)$ (data not shown).

\section{Flow and apparent digestibility of DM and nitrogen}

The flow of DM in the faeces, but not at the ileum and in the colon, increased linearly $(P<0 \cdot 001)$ with increasing the level of raw phaseolin in the diet (Table 3 ). As a result, the apparent faecal digestibility of DM decreased quadratically with increasing the level of phaseolin $(P<0 \cdot 001)$. The ileal digestibility of DM was not influenced by this factor. The flow of $\mathrm{N}$ at all digestive sites increased linearly with increasing the level of unheated phaseolin in the diet $(P=0.011$ to $<0.001)$. As a consequence, both ileal and faecal digestibilities of $\mathrm{N}$ decreased linearly with increasing dietary phaseolin level $(P<0 \cdot 001)$. Heat treatment of phaseolin reduced DM and $\mathrm{N}$ flows along the intestines and increased DM and $\mathrm{N}$ digestibilities $(P<0 \cdot 001)$ to values close to those observed with the casein-based control diet.

\section{Flow of mucin along the gastrointestinal tract and tissue} expression of mucin family genes

The enzyme-linked lectin assay test revealed no binding with casein or phaseolin or with the experimental diets, indicating the lack of carbohydrate moieties recognised by wheat germ agglutinin in these ingredients and diets. The flow of mucin in the colon decreased linearly with increasing the dietary phaseolin level $(P<0.001)$ (Table 3). This factor did not influence the flow of mucin at the ileum or in the faeces $(P>0.05)$. The colonic flow of mucin was lower with $\mathrm{P} 67-\mathrm{H}$ than with the casein control $(P<0 \cdot 05)$, but it was not different from that with unheated phaseolin (P67) (probabilities of differences for $\mathrm{P} 0 v$. $\mathrm{P} 67, \mathrm{P} 0 \quad v$. $\mathrm{P} 67-\mathrm{H}$ and $\mathrm{P} 67 v$. $\mathrm{P} 67-\mathrm{H}$ : $P=0.001,0.003$ and $0 \cdot 288$, respectively).

The expression of Muc3 and Muc4 mRNA tended to decrease quadratically $(P=0.060$ and 0.090 , respectively) in the ileal tissue and increased or tended to increase linearly $(P=0.093$ and 0.023 , respectively) in the colonic tissue as the dietary level of unheated phaseolin increased in the diet (Table 4). By contrast, the expressions of Muc1, Muc2 and Tff3 mRNA in the ileal and colonic tissue were not influenced by the level of unheated phaseolin in the diet $(P>0 \cdot 1)$.

The expression of Muc genes and Tff3 tended to be influenced by heat treatment of phaseolin in colonic tissues, except for the Mucl gene (Fig. 1). mRNA expressions of $M u c 2, M u c 3, M u c 4$ and Tff3 were lower with heat-treated phaseolin than unheated phaseolin $(P<0 \cdot 001$ to $<0 \cdot 05)$. mRNA expression of the Muc family genes and Tff3 in ileal tissues was not influenced by heat treatment of phaseolin $(P>0.05)$. Muc2 mRNA levels were lower in ileal and colonic tissues of rats fed the heat-treated phaseolin diet than in those fed the casein-based control diet $(P=0.003$ and 0.001 , respectively). Finally, Muc2 gene expression in the ileal tissue was lower $(P=0.004)$, and those of Muc3 and Muc4 in the colonic tissue of rats fed unheated phaseolin tended to be higher $(P=0.058$ and 0.005$)$ when compared with the corresponding tissues of rats fed the casein-based control diet.

\section{Discussion}

The present investigation shows for the first time that phaseolin intake and heat treatment can modulate mucin flow and mRNA levels of various mucin genes in the gut tissues of rats.

Table 3. DM, nitrogen and mucin flows along the gastrointestinal tract, and apparent ileal and faecal digestibilities of DM and nitrogen in rats fed graded levels of unheated phaseolin and of heat-treated phaseolin ( $n 4-5)$

\begin{tabular}{|c|c|c|c|c|c|c|c|c|c|}
\hline & \multirow{2}{*}{\multicolumn{4}{|c|}{ Treatment $^{*}$}} & \multicolumn{3}{|c|}{ Level of unheated phaseolin† } & \multirow{2}{*}{\multicolumn{2}{|c|}{ Heat treatment $\ddagger$}} \\
\hline & & & & & \multirow[b]{2}{*}{ SEM } & \multicolumn{2}{|c|}{$P$ contrast } & & \\
\hline & Po & P33 & P67 & $\mathrm{P} 67-\mathrm{H}$ & & Linear & Quadratic & SEM & $P$ \\
\hline \multicolumn{10}{|l|}{ DM flow (mg/g DM intake) } \\
\hline Ileum & 221 & 230 & 275 & 215 & 21 & 0.130 & 0.512 & 26 & 0.280 \\
\hline Colon & 110 & 123 & 116 & 117 & 10 & 0.664 & 0.432 & 7 & 0.740 \\
\hline Faeces & $103^{\mathrm{b}}$ & 102 & $140^{\mathrm{a}}$ & $96^{\mathrm{b}}$ & 7 & 0.001 & 0.008 & 12 & 0.001 \\
\hline \multicolumn{10}{|l|}{$\mathrm{N}$ flow (mg/g N intake) } \\
\hline Ileum & $100^{\mathrm{b}}$ & 300 & $416^{\mathrm{a}}$ & $102^{b}$ & 29 & 0.001 & 0.598 & 16 & 0.001 \\
\hline Colon & $14 b^{b}$ & 139 & $254^{\mathrm{a}}$ & $59^{b}$ & 39 & 0.004 & 0.871 & 26 & 0.001 \\
\hline Faeces & $92^{\mathrm{b}}$ & 173 & $427^{\mathrm{a}}$ & $105^{\mathrm{b}}$ & 20 & 0.001 & 0.007 & 19 & 0.001 \\
\hline \multicolumn{10}{|l|}{ DM apparent digestibility (\%) } \\
\hline Ileum & 0.78 & 0.77 & 0.73 & 0.79 & 0.02 & 0.130 & 0.512 & 0.03 & 0.280 \\
\hline Faeces & $0.90^{\mathrm{a}}$ & 0.90 & $0.86^{\mathrm{b}}$ & $0.90^{\mathrm{a}}$ & 0.01 & 0.001 & 0.008 & 0.01 & 0.001 \\
\hline \multicolumn{10}{|l|}{$\mathrm{N}$ apparent digestibility (\%) } \\
\hline Ileum & $0.90^{\mathrm{a}}$ & 0.70 & $0.59^{b}$ & $0.90^{\mathrm{a}}$ & 0.02 & 0.001 & 0.160 & 0.02 & 0.001 \\
\hline Faeces & $0.91^{\mathrm{a}}$ & 0.83 & $0.57^{\mathrm{b}}$ & $0.91^{\mathrm{a}}$ & 0.02 & 0.001 & 0.007 & 0.02 & 0.001 \\
\hline \multicolumn{10}{|l|}{ Mucin flow } \\
\hline Ileum ( $\mu \mathrm{g} / \mathrm{g}$ DM intake) & 2149 & 2358 & 2443 & 2292 & 382 & 0.619 & 0.895 & 329 & 0.830 \\
\hline Colon (ng/g DM intake) & $539^{a}$ & 238 & $171^{b}$ & $248^{b}$ & 34 & 0.001 & 0.025 & 120 & 0.002 \\
\hline Faeces (ng/g DM intake) & 85 & 57 & 66 & 57 & 12 & 0.279 & 0.280 & 11 & 0.250 \\
\hline
\end{tabular}

a,b Values within a row with unlike superscript letters between $\mathrm{P} 0, \mathrm{P} 67$ and $\mathrm{P} 67-\mathrm{H}$ treatments were significantly different $(P<0 \cdot 05)$.

* P0, casein control; P33 and P67, diets with unheated phaseolin contributing to 330 and $670 \mathrm{~g} / \mathrm{kg}$ of the total dietary protein in the diet; P67-H, diet with heated phaseolin contributing to $670 \mathrm{~g} / \mathrm{kg}$ of total protein in the diet.

† Comparisons between diets P0, P33 and P67.

$\ddagger$ Comparisons between diets P0, P67 and P67-H. 
Table 4. Mucin (Muc) gene expression in ileal and colonic tissues of rats fed graded levels of unheated phaseolin $(n 4-5)$

\begin{tabular}{cccccccc}
\hline & \multicolumn{3}{c}{ Treatment* $^{*}$} & & \multicolumn{2}{c}{$P$ contrast } \\
\cline { 3 - 4 } & P0 & P33 & P67 & SEM & Linear & Quadratic \\
\hline lleum & & & & & & \\
Muc1 & 1.74 & 1.25 & 1.82 & 0.41 & 0.866 & 0.342 \\
Muc2 & 6.83 & 6.96 & 5.41 & 0.60 & 0.110 & 0.253 \\
Muc3 & 0.85 & 1.08 & 0.76 & 0.10 & 0.540 & 0.060 \\
Muc4 & 1.69 & 1.37 & 1.52 & 0.11 & 0.255 & 0.093 \\
Tff3 & 1.48 & 1.28 & 1.57 & 0.17 & 0.697 & 0.253 \\
Colon & & & & & & \\
Muc1 & 3.80 & 3.06 & 2.14 & 0.93 & 0.171 & 0.928 \\
Muc2 & 5.69 & 4.90 & 5.35 & 0.51 & 0.625 & 0.304 \\
Muc3 & 3.82 & 5.95 & 6.32 & 1.03 & 0.090 & 0.434 \\
Muc4 & 3.04 & 4.95 & 5.48 & 0.62 & 0.023 & 0.355 \\
Tff3 & 2.75 & 3.40 & 3.23 & 0.39 & 0.421 & 0.407 \\
\hline
\end{tabular}

Tff3, trefoil factor 3 .

* P0, casein control; P33 and P67, diets with unheated phaseolin contributing to 330 and $670 \mathrm{~g} / \mathrm{kg}$ of the total dietary protein in the diet.

Influence of phaseolin on mucin flow and gut tissue expression of Muc family genes

Santoro et al. ${ }^{(6)}$ based on acute feeding experiments assumed that the poor nutritional value of unheated phaseolin was due to increased intestinal losses of endogenous $\mathrm{N}$, suggestively mucin, when the level of phaseolin increased in the diet. The present results do not support this view because raw phaseolin intake did not increase mucin flow at the end of the small intestine and did not alter intestinal mRNA levels of $M u c 2$, the main component of intestinal secreted mucin $^{(21)}$. The discrepancies between the present investigation and studies by Santoro et al. ${ }^{(6,22)}$ may come from different experimental approaches (acute $v$. repeated feeding experiments) or from methodologies for evaluating endogenous $\mathrm{N}$ losses. The present data are consistent with our previous observations showing limited effects of phaseolin on intestinal anatomy and enzyme activities ${ }^{(7,15)}$

We observed that dietary phaseolin level and heat treatment influenced the expression of Muc2, Muc3 and Muc4 and Tff3 genes in different ways along the intestines. The actual reasons for these effects and the possible consequences in terms of gut protection are not fully understood yet. Mucin 2 is the major component of mucin secreted along the gastrointestinal tract ${ }^{(21)}$. Muc2 knock out mice develop colitis spontaneously, indicating the important role of this mucin in colonic protection $^{(23)}$. In the present study, both unheated and heattreated phaseolin reduced $M u c 2$ gene expression in the ileum, and heat treatment of phaseolin reduced Muc2 gene expression in the colon as compared to the casein control (Fig. 1). These observations may suggest a potentially weaker gut protection following phaseolin intake, with differential effects in the ileum and the colon depending on phaseolin cooking.

Muc3 contributes to the protection of the intestinal epithelium. A higher intestinal expression of $M u c 3$ mRNA following hypoxia suggests a protective mechanism during episodes of diminished oxygen delivery ${ }^{(24)}$. Conversely, a reduction in $M u c 3$ mRNA levels has been reported in Crohn's disease patients ${ }^{(25)}$. In the present study, the level of unheated phaseolin in diets affected Muc3 mRNA levels in opposite ways depending on the intestinal segment: it decreased in ileal tissue and increased in colonic tissue. These results suggest that ileal Muc3 gene expression may be negatively regulated by ileal $\mathrm{N}$ flow, while that of colonic Muc3 may be positively regulated by colonic $\mathrm{N}$ flow. Although the correlation between ileal Muc3 mRNA level and ileal $\mathrm{N}$ flow did not reach significance, colonic Muc3 mRNA level was found to be positively correlated to colonic $\mathrm{N}$ flow $(r \quad 0.70, P<0.05)$. Heat treatment of phaseolin decreased the expression of Muc3 mRNA in the colon, an observation that supports the latter assumption. Further work is needed to demonstrate causal links between mucin gene expression and digesta flow or fermentation in order to contribute to explain regional variations in the expression of these genes along the gut.

The Muc4 gene is expressed in cells at the basement of crypts in the small intestine, but its expression is higher in the colon where it is located in goblet cells ${ }^{(26)}$. Muc4 appears to play important roles in epithelial growth, cell differentiation $^{(27)}$, mucosal defence ${ }^{(28)}$ and intestinal lubrication ${ }^{(26)}$. In the present study, the increased expression of Muc4 mRNA levels in colonic tissues and the trend in ileal tissues, in response to increased levels of dietary phaseolin, could not be explained by changes in the flow of DM (or fresh digesta) in the ileum and the colon that were NS. Heat-treated phaseolin also reduced the expression of Muc4 mRNA.

The trefoil family 3 (Tff3) gene is also expressed in the mucin secretory cells. It helps to protect and stabilise the mucus layer and heal the epithelium ${ }^{(29)}$. As for the $M u c$ family genes (except $M u c 1$ ), a reduction in the expression of Tff 3 mRNA in the colonic tissue after thermal treatment of phaseolin was observed. A positive association between intestinal trefoil factor and Muc3 expressions has been linked with mucosal hypoxia and altered epithelial barrier function ${ }^{(24)}$.

The link between $M u c$ gene tissue expressions and mucin flow along the intestines does not seem to be straightforward, because this flow reflects the balance between mucin production and luminal degradation by the microbiota ${ }^{(8)}$ and also because $M u c$ gene expression varies regionally along gut compartments for a given diet ${ }^{(30)}$. The most consistent point in the present study was the lower colonic mucin flow with heated phaseolin, which could reflect at least partly the lower colonic Muc2 mRNA levels with this diet. By contrast, Muc gene levels and mucin flow varied in different ways along the gut according to the dietary treatments (e.g. in the ileum, the casein-based control diet had similar mucin flow and higher Muc2 gene expression than phaseolin-containing diets).

In previous studies with longer periods of feeding (2 weeks) similar phaseolin-based diets, we did not observe health problems or important alterations in gut anatomy and enzyme activities $^{(15)}$. Therefore, it can be suggested that the changes in the expression of $M u c$ genes in gut tissues (mainly in colon) as noted here might have had little effect on gut function, at least in our experimental conditions.

\section{Nutritional factors modulating Muc gene expression and mucin synthesis}

A number of studies suggest that casein may influence

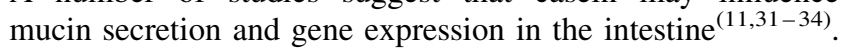
Varying the level and the origin (animal $v$. plant) of protein in milk formulas modulated mucin gut flow in baby calves ${ }^{(11)}$. 

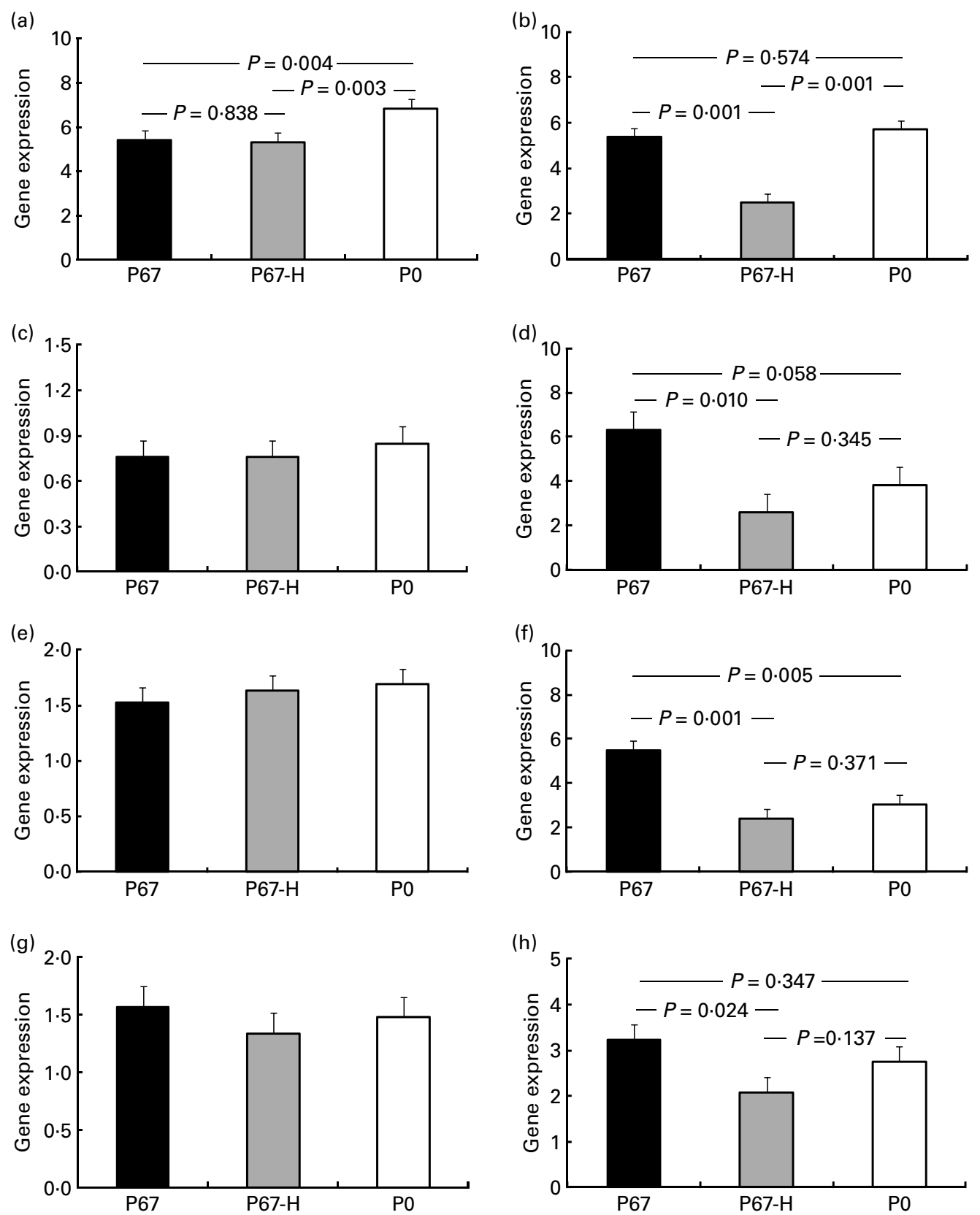

Fig. 1. Influence of heat treatment of phaseolin on mucin (Muc) and trefoil factor 3 (Tff3) gene expression in ileal and colonic tissues of rats: Muc2 in the ileum (a); Muc2 in the colon (b); Muc3 in the ileum (c); Muc3 in the colon (d); Muc4 in the ileum (e); Muc4 in the colon (f); Tff3 in the ileum (g); Tff3 in the colon (h). Values are means $(n 4-5)$, with their standard errors represented by vertical bars. P0, casein control diet; P67, diet containing phaseolin at $670 \mathrm{~g} / \mathrm{kg}$ total protein; $\mathrm{P} 67-\mathrm{H}$, diet containing heat-treated phaseolin at $670 \mathrm{~g} / \mathrm{kg}$ total protein. The overall probabilities for treatment effects were for Muc2 $(P=0.004$ and 0.001$), M u c 3$ $(P=0.789$ and 0.027$)$, Muc4 $(P=0.732$ and 0.003$)$ and Tff3 $(P=0.432$ and 0.062$)$ in the ileum and in the colon, respectively.

Hydrolysed casein increased ileal endogenous amino acid losses in human subjects ${ }^{(31)}$ and gut tissue Muc3 and Muc4 mRNA levels in rats ${ }^{(32)}$. Hydrolysed casein and related peptides (e.g. $\beta$-casomorphin-7) also induced mucin secretion in isolated and perfused rat jejunum ${ }^{(33)}$ and increased the expression of $M u c 2$ and $M u c 3$ genes in intestinal mucinproducing cells ${ }^{(34)}$. Here, casein may have been responsible for the higher Muc2 mRNA levels observed in the ileal tissues. However, in the colon, Muc gene expression was similar to or higher than those observed with casein when the level of unheated phaseolin increased in the diet. Possible effects of casein peptides on intestinal mucin gene expression and flow make the interpretation of data more difficult in studies where casein is used as the control and is substituted with other protein sources (e.g. phaseolin), as in the present study. However, it must be borne in mind that luminal concentrations of casein peptides, including that of $\beta$-casomorphin-7 after milk or casein intake, have never been determined in vivo ${ }^{(33)}$. Also, two independent studies revealed that the bioactive peptide $\beta$-casomorphin-7 is not detected in digests after casein digestion in vitro ${ }^{(35,36)}$. Additionally, the demonstration of $\beta$-casomorphin-7 secretory properties on jejunal mucin with isolated and perfused rat jejunum ${ }^{(33)}$ does not provide evidence for such effects on the ileum or the colon, 
the two sites under study in the present study. Finally, results from investigations with hydrolysed casein ${ }^{(31,33)}$ do not mean that entire casein that is subsequently hydrolysed by endogenous proteases and peptidases may have resulted in the same effects as exogenously hydrolysed casein on mucin flow and gene expression. Collectively, there is no evidence to date showing that casein peptides (like $\beta$-casomorphin-7) are released during casein digestion and are bioactive in vivo. Therefore, the most reasonable interpretation of the present data is that phaseolin was responsible for the observed changes in intestinal mucin flow and gene expression.

Dietary threonine is also important to consider because it is highly represented in mucin, its dietary restriction reduces intestinal mucin synthesis specifically ${ }^{(37,38)}$ and it may become a limiting amino acid for mucin synthesis in intestinal inflammation in rats and pigs ${ }^{(39,40)}$. Threonine restriction reduced $M u c$ gene expression in the small and large intestines of rats ${ }^{(39)}$. According to the amino acid composition of casein and phaseolin ${ }^{(41)}$ and the ileal digestibility of $\mathrm{N}$ in the present diets, the theoretical availability of amino acids decreased as the level of unheated phaseolin increased in the diet. The casein-based control diet provided 25 and $68 \%$ more threonine than phaseolin P33 and P67 diets, respectively. These diets with unheated phaseolin did not lead to a reduction in ileal mucin flow. The limited threonine supply with the unheated phaseolin-containing diets may have been responsible at least partly for the changes recorded in the ileal Muc gene expression in the present study. In the colon, the mucin flow decreased in proportion to the unheated phaseolin included in the diet. This could have been caused by bacterial fermentation being stimulated by indigested phaseolin components, thus leading to enhanced mucin degradation in the colon. Dietary protein type and amino acid composition influence the colonic microbiota and resulting profiles of SCFA, which, in turn, modulate the mucus layer ${ }^{(8,12)}$ and the expression of secreted (Muc2) and membrane-bound (Muc1, Muc3 and Muc4) mucins ${ }^{(30,42,43)}$. It can partially explain the increased proportion of Muc3 and Muc4 gene expressions as dietary unheated phaseolin was included in the diet.

Although the casein control diet and the heat-treated phaseolin diet had similar and high digestibilities, they displayed different Muc2 mRNA levels in ileal and colonic tissues and different colonic mucin flow. Both of these observations could be explained by the $\beta$-casomorphin- 7 peptides of casein $^{(33)}$ and/or changes in microbiota ${ }^{(30,42,43)}$ as explained above. New investigations are needed to determine the influence of phaseolin on gut fermentation profiles and possible links with gut $M u c$ gene expression.

\section{Effect of phaseolin on digesta flow along the gastrointestinal tract and on digestibility}

The present results revealed increased flows of DM and $\mathrm{N}$ that led to a reduction in apparent $\mathrm{N}$ digestibility in rats fed with the highest level of unheated phaseolin in the diet, in agreement with our previous studies ${ }^{(15)}$. The low nutritional value of unheated phaseolin consumed chronically may be due mainly to its high resistance to enzymatic hydrolysis, as evidenced by increased ileal and faecal output of undigested phaseolin polypeptides ${ }^{(44)}$. Heat treatment of phaseolin reduced ileal and faecal $\mathrm{N}$ output, thus increasing the apparent digestibility of $\mathrm{N}$. These observations are in agreement with previous investigations ${ }^{(2,7,45,46)}$. Recently, we showed that these improvements were related to the disappearance of undigested phaseolin polypeptides in ileal digesta following heat treatment of phaseolin ${ }^{(15,44)}$.

In conclusion, the present study provides evidence that the level and the source of protein influence the flow of mucin and the expression of various $M u c$ family genes in the ileal and colonic tissues. Additionally, we showed that different sources of protein (casein $v$. phaseolin) with similar digestibility could influence $M u c$ gene expression in the intestines differentially. Further work is required to elucidate the actual mechanisms of $M u c$ gene modulation by phaseolin and to evaluate the possible functional outcomes of phaseolin intake in terms of gut protection.

\section{Acknowledgements}

The authors thank the Volkswagen Foundation (Hannover, Germany), COLCIENCIAS (Bogotá, Colombia), ECOS-Nord (Université de Paris 5, France) and Conseil Régional de Bretagne (Rennes, France) for financial support. The study was not subject to conflicts of interest of any kind. The research is public. The bean varieties containing the different phaseolin types are available to research scientists at the International Centre of Tropical Agriculture, as long as they are not commercialised afterwards. P. L., J. C. and J.-P. L. designed the study and revised the manuscript; C. A. M. did the laboratory work and prepared the manuscript under the supervision of J.-P. L.; S. B. produced the beans and the phaseolins; and V. R. did the gene expression analysis.

\section{References}

1. Ma Y \& Bliss F (1978) Seed proteins of common bean. Crop Sci 18, 431-437.

2. Marquez U \& Lajolo F (1981) Composition and digestibility of albumin, globulins, and glutelins from Phaseolus vulgaris. J Agric Food Chem 29, 1068-1074.

3. Jivotovskaya A, Senyuk V, Rotari V, et al. (1996) Proteolysis of phaseolin in relation to its structure. J Agric Food Chem 44, 3768-3772.

4. Deshpande SS \& Nielsen SS (1987) In vitro enzymatic hydrolysis of phaseolin, the major storage protein of Phaseolus vulgaris L. J Food Sci 52, 1326-1329.

5. Deshpande SS \& Damodaran S (1989) Structure-digestibility relationship of legume 7S proteins. J Food Sci 54, 108-113.

6. Santoro LG, Grant G \& Pusztai A (1999) In vivo degradation and stimulating effect of phaseolin on nitrogen secretion in rats. Plant Foods Hum Nutr 53, 223-236.

7. Montoya CA, Lallès JP, Beebe $\mathrm{S}$, et al. (2006) Influence of the Phaseolus vulgaris phaseolin level of incorporation, type and thermal treatment on gut characteristics in rats. Br J Nutr 95, 116-123.

8. Montagne L, Piel C \& Lallès JP (2004) Effect of diet on mucin kinetics and composition: nutrition and health implications. Nutr Rev 62, 105-114.

9. Engel E, Guth PH, Nishizaki Y, et al. (1995) Barrier function of the gastric mucus gel. Am J Physiol 269, G994-G999.

10. Lien KA, Sauer WC \& Fenton M (1997) Mucin output in ileal digesta of pigs fed a protein-free diet. Ernährungswiss 36, 182-190.

11. Montagne L, Toullec R, Formal M, et al. (2000) Influence of dietary protein level and origin on the flow of mucin along 
the small intestine of the preruminant calf. $J$ Dairy Sci $\mathbf{8 3}$, $2820-2828$

12. Toden S, Bird AR, Topping DL, et al. (2007) Differential effects of dietary whey, casein and soya on colonic DNA damage and large bowel SCFA in rats fed diets low and high in resistant starch. Br J Nutr 97, 535-543.

13. Hall TC, McLeester RC \& Bliss FA (1977) Equal expression of the maternal and paternal alleles for polypeptide subunits of the major storage protein of the bean Phaseolus vulgaris L. Plant Physiol 59, 1122-1124.

14. Mrad de Osorio A \& Cardozo de Martinez C (1999) Principios basicos para el manejo de animales de laboratorio (Basic Principles for the Handling of Laboratory Animals). Bogota: Universidad Nacional de Colombia.

15. Montoya CA, Leterme P, Beebe S, et al. (2008) Phaseolin type and heat treatment influence the biochemistry of protein digestion in rat intestine. Br J Nutr 99, 531-539.

16. Trompette A, Blanchard C, Zoghbi S, et al. (2004) The DHE cell line as a model for studying rat gastro-intestinal mucin expression: effects of dexamethasone. Eur J Cell Biol 83, $347-358$

17. Giulietti A, Overbergh L, Valckx D, et al. (2001) An overview of real-time quantitative PCR: applications to quantify cytokine gene expression. Methods 25, 386-401.

18. Furukawa A \& Tsukahara H (1966) On the acid digestion method for the determination of chromic oxide as an index substance in the study of digestibility of fish fed. Bull Jpn Soc Sci Fisheries 32, 502-506.

19. Montoya CA, Gomez AS, Lallès JP, et al. (2008) In vitro and in vivo protein hydrolysis of beans (Phaseolus vulgaris) genetically modified to express different phaseolin types. Food Chem 106, 1225-1233.

20. Steel RGD \& Torrie JH (1980) Principles and procedures of statistics., 2nd ed New York, NY: McGraw-Hill.

21. Corfield AP, Myerscough N, Longman R, et al. (2000) Mucins and mucosal protection in the gastrointestinal tract: new prospects for mucins in the pathology of gastrointestinal disease. Gut 47, 589-594.

22. Santoro LG, Grant G \& Pusztai A (1997) Effects of short-term feeding of rats with a highly purified phaseolin preparation. Plant Foods Hum Nutr 51, 61-70.

23. Van der Sluis M, De Koning BA, De Bruijn AC, et al. (2006) Muc2-deficient mice spontaneously develop colitis, indicating that MUC2 is critical for colonic protection. Gastroenterology 131, 117-129.

24. Louis NA, Hamilton KE, Canny G, et al. (2006) Selective induction of Mucin-3 by hypoxia in intestinal epithelia. $J$ Cell Biochem 99, 1616-1627.

25. Corfield AP, Myerscough N, Longman R, et al. (2000) Mucin and mucosal protection in the gastrointestinal tract: new prospects for mucins in the pathology of gastrointestinal tract. Gut 47, 589-594.

26. Rong M, Rossi EA, Zhang J, et al. (2005) Expression and localization of Muc4/sialomucin complex (SMC) in the adult and developing rat intestine: implications for Muc4/SMC function. J Cell Physiol 202, 275-284.

27. Rossi EA, McNeer RR, Price-Schiavi SA, et al. (1996) Sialomucin complex, a heterodimeric glycoprotein complex. Expression as a soluble, secretable form in lactating mammary gland and colon. J Biol Chem 271, 33476-33485.

28. Hoebler C, Gaudier E, De Coppet P, et al. (2006) MUC genes are differently expressed during onset and maintenance of inflammation in dextran sodium sulphate-treated mice. Dig Dis Sci 51, 381-389.

29. Kindon H, Pothoulakis C, Thim L, et al. (1995) Trefoil peptide protection of intestinal epithelial barrier function: cooperative interaction with mucin glycoprotein. Gastroenterology $\mathbf{1 0 9}$, $516-523$.

30. Hedemann MS, Theil PK \& Bach Knudsen KE (2009) The thickness of the intestinal mucous layer in the colon of rats fed various sources of non-digestible carbohydrates is positively correlated with the pool of SCFA but negatively correlated with the proportion of butyric acid in digesta. Br J Nutr 102, $117-125$

31. Moughan PJ, Butts CA, Rowan AM, et al. (2005) Dietary peptides increase endogenous amino acid losses from the gut in adults. Am J Clin Nutr 81, 1359-1365.

32. Han K, Deglaire A, Sengupta R, et al. (2008) Hydrolyzed casein influences intestinal mucin gene expression in rat. J Agric Food Chem 56, 5572-5576.

33. Claustre J, Toumi F, Trompette A, et al. (2002) Effects of peptides derived from dietary proteins on mucus secretion in rat jejunum. Am J Physiol Gastrointest Liver Physiol 283, G521-G528.

34. Zoghbi S, Trompette A, Claustre J, et al. (2006) $\beta$-Casomorphin-7 regulates the secretion and expression of gastrointestinal mucins through a $\mu$-opioid pathway. Am J Physiol Gastrointest Liver Physiol 290, G1105-G1113.

35. Schmelzer CE, Schöps R, Reynell L, et al. (2007) Peptic digestion of beta-casein. Time course and fate of possible bioactive peptides. J Chromatogr A 1166, 108-115.

36. Picariello G, Ferranti P, Fierro O, et al. (2010) Peptides surviving the simulated gastrointestinal digestion of milk proteins: biological and toxicological implications. $J$ Chromatogr $B$ Analyt Technol Biomed Life Sci. 878, 295-308.

37. Faure M, Moënnoz D, Montigon F, et al. (2005) Dietary threonine restriction specifically reduces intestinal mucin synthesis in rats. $J$ Nutr $\mathbf{1 3 5}, 486-491$.

38. Nichols NL \& Bertolo RF (2008) Luminal threonine concentration acutely affects intestinal mucosal protein and mucin synthesis in piglets. $J$ Nutr 138, 1298-1303.

39. Faure M, Mettraux C, Moennoz D, et al. (2006) Specific amino acids increase mucin synthesis and microbiota in dextran sulfate sodium-treatred rats. $J$ Nutr 136, 1558-1564.

40. Rémond D, Buffière C, Godin JP, et al. (2009) Intestinal inflammation increases gastrointestinal threonine uptake and mucin synthesis in enterally fed minipigs. J Nutr 139, $720-726$.

41. Montoya CA, Leterme P, Victoria NF, et al. (2008) Susceptibility of phaseolin to in vitro proteolysis is highly variable across common bean varieties (Phaseolus vulgaris). J Agric Food Chem 56, 2183-2191.

42. Burger-van Paassen N, Vincent A, Puiman PJ, et al. (2009) The regulation of intestinal mucin MUC2 expression by short-chain fatty acids: implications for epithelial protection. Biochem J 420, 211-219.

43. Gaudier E, Rival M, Buisine MP, et al. (2009) Butyrate enemas upregulate $M u c$ genes expression but decrease adherent mucus thickness in mice colon. Physiol Res 58, 111-119.

44. Montoya CA, Lallès JP, Beebe S, et al. (2009) Susceptibility of phaseolin (Phaseolus vulgaris) subunits to trypsinolysis and influence of dietary level of raw phaseolin on protein digestion in the small intestine of rats. Br J Nutr 101, 1324-1332.

45. Liener I \& Thompson R (1980) In vitro and in vivo studies of the digestibility of the major storage protein of the navy bean Phaseolus vulgaris. Plant Foods Hum Nutr 30, 13-25.

46. Marquez U \& Lajolo F (1990) Nutritional value of cooked beans (Phaseolus vulgaris) and their isolated major protein fractions. J Sci Food Agric 53, 235-242.

47. Lin J, Ho S, Shekels L, et al. (1999) Mucin gene expression in the rat middle ear: an improved method for RNA harvest. Ann Otol Rhinol Laryngol 108, 762-768. 